\title{
Developing EFL Writing with Year 5 Pupils by Writing Summaries
}

\begin{abstract}
Developing EFL writing skills in primary school pupils is one of the most demanding and time consuming challenges that foreign language teachers face. The main aim of this study was thus to analyse 64 written summaries of Year 5 pupils in terms of content, structure, length and most often used words. In order to achieve the aim of pupils being able to write a summary of a story individually and in a given time frame, the task was approached gradually and systematically throughout the school year. The results show that most of the pupils managed to finish a structurally organized summary and most of them wrote a summary which included the most important aspects regarding the content of the story. The results of the survey indicate that a systematic approach to writing summaries helps pupils in developing their writing skills.
\end{abstract}

Keywords: English as a foreign language; primary school pupils; summary; writing skills

\section{Razvijanje pisnih spretnosti v tujem jeziku pri petošolcih $s$ pisanjem obnov}

POVZETEK

Razvijanje pisnih spretnosti $\mathrm{v}$ angleščini kot tujem jeziku pri osnovnošolskih učencih je eden izmed najbolj zahtevnih in časovno obsežnih izzivov, s katerimi se soočajo učitelji tujih jezikov. Glavni namen te študije je bil analizirati 64 pisnih obnov petošolcev glede na vsebino, strukturo, dolžino besedila in najpogosteje uporabljene besede. Za dosego cilja, pri katerem so učenci sposobni individualno napisati obnovo v določenem času, je bil potreben postopen in sistematičen pristop $\mathrm{k}$ pisanju skozi vse šolsko leto. Rezultati kažejo, da je večini učencev uspelo v celoti napisati strukturno organizirano obnovo in da je večina napisala obnovo, v kateri so bili upoštevani najpomembnejši vsebinski vidiki zgodbe. Rezultati raziskave nakazujejo, da sistematičen pristop $\mathrm{k}$ pisanju obnov pozitivno prispeva $\mathrm{k}$ razvijanju pisnih spretnosti.

Ključne besede: obnova; osnovnošolski učenci; pisna spretnost; tuji jezik angleščina 


\section{Developing EFL Writing with Year 5 Pupils by Writing Summaries}

\section{Introduction}

English language learning is starting at an earlier age across the globe. In Slovenia compulsory English instruction now starts at the age of seven and, for at least the first couple of years focuses primarily on developing listening and speaking, while reading and writing skills are gradually introduced in later years. However, The National Examinations Centre's (RIC 2014; RIC 2015; RIC 2016; RIC 2017) conclusions over the past four years point out that the writing skills of Year 6 pupils are not achieving an adequate level according to the national syllabus for English (2016). This could be the case because national syllabuses for teaching foreign languages are often designed with no reference to any results based on literacy research and therefore offer little support to teachers of foreign languages (Dagarin Fojkar, Sešek, and Skela 2011, 19). There are no step-by-step guidelines on how to approach writing systematically and teachers are left to their own devices to construct appropriate activities and support pupils in this complex process. Consequently, teaching literacy skills is left to chance, and is a by-product of learning foreign languages (Dagarin Fojkar, Sešek, and Skela 2011, 19). In Slovenia, the development of foreign language literacy skills in primary school has not been carried out in a sufficiently systematic way (Dagarin Fojkar 2014), leading to considerable differences among pupils' writing skills.

\section{Theoretical Background}

"Research on the writing process, the most complex cognitive domain of language, has led to what is now the dominant paradigm in writing instruction, the process approach" (Cushing Weigle 2014, 226). Brown $(2001,320)$ states that "a few decades ago writing teachers were mostly concerned with the final product of writing and what that product should look like". Learners were required to write compositions in a set style following accurate grammar and conventional text organization (Brown 2001). In recent years, however, teachers have encouraged learners to create their own texts, focusing on content and message, and thus putting learners' intrinsic motives as the starting point of learning (Brown 2001). According to Shih (1986), process approaches are of an intrinsic nature because they: focus on the process of writing and do not put the final product at the centre of learning; help learners to understand the writing process; help them with strategies for prewriting, drafting, and rewriting; give learners ample time to write; emphasise the process of revision; offer learners feedback throughout the entire writing process and provide learners individual help during the writing process.

Hirvela (2016) provides a convincing rationale for including reading as an integral component of the writing classroom. One of his main areas of source-based writing is reading for writing, which is divided in the input (reading) and the output (writing) orientation. "Reading quite clearly provides invaluable input for helping individuals visualize what writing looks like in the target language" (Hirvela 2016, 48). Brown writes $(2001,330)$ :

Clearly students learn to write in part by carefully observing what is already written. That is, they learn by observing, or reading, the written word. By reading and studying a variety of relevant types of text, students can gain important insights both about how they should write and about subject matter that may become the topic of their writing. 
Stotsky $(1995,773)$ summarizes the benefits of reading texts before writing them by observing that: "Reading experience would seem to be the chief source of a developing writer's syntactic, generic, and lexical knowledge". Moreover, in line with Hirvela (2016, 49), "reading also provides writers with essential material to write with and about; the output orientation concerns the writing that follows the reading".

Summary writing is one of the most obvious activities after reading, despite not being a simple task. Cho (2012) claims that most pupils have difficulties writing summaries in their first language, and even more in a foreign language and although foreign language teachers see summary writing as an important skill, they lack the knowledge of how to teach it.

Many authors (Friend 2001; Westby et al. 2010; Langan 2015) have offered their definitions of a summary. Behrens and Rosen $(2012,3)$ define it as follows: "By summary we mean a brief restatement, in your own words, of the content of the passage (a group of paragraphs, a chapter, an article, a book). This restatement should focus on the central idea of the passage." Kirkland and Saunders $(1991,105)$ state that summarizing is "a highly complex, recursive reading-writing activity", and as such cognitively very demanding for learners. According to Cho (2012), the most important skill in summary writing is establishing the key ideas in the text, although Rinehart and Thomas (1993) emphasize the importance of reflection and decision making in the process of summary writing. Regarding the process rules of summary writing Hill (1991) lists the following components: text difficulty and organisation, comprehensibility and availability of text, intended audience and the purpose of writing, genre and text length. Brown and Day (1983) add the following: deletion of unimportant and redundant information, the use of hypernyms and careful selection of a topic sentence.

Johnson (1983) proposes six steps in writing story summaries. The first is understanding the text ideas, followed by connecting these ideas, identifying the text structure and remembering the content of the story. The last two steps are related to the actual writing of the story, i.e. selecting which information to include in the writing and formulating a coherent text (Johnson 1983). According to Brown and Day (1983) children are capable of excluding unimportant information at quite an early age, provided that the material they are summarizing is age-appropriate. Planning, which is a metacognitive process, plays an essential role in writing summaries. In fact, Hidi and Anderson $(1986,481)$ argue that "planning improved younger children's performances, and that adequate planning, which gradually emerges in development, is of central importance in summarizing."

Research on developing children's writing skills in English as a foreign language is much scarcer than research on developing children's reading or speaking skills (Murphy 2017). Lindgren and Stevenson (2013) examined the use of interactional resources in letters to a pen friend among Swedish 11-year-old pupils in their first language and in English as a foreign language. The main aims of their research were to investigate whether the language of the letters and the gender of the writers had an impact on their expression of interactional meanings, and to analyse the resources that the pupils employed to express interactional meanings in English. The results showed that there were not many differences in the frequency of interactional meanings in the two languages. However, there were a few more differences found in relation to gender, with girls using more interactional meanings than boys and writing longer letters than boys. The texts were significantly longer in the first language than in the foreign language. The pupils used many non-linguistic resources to express the meanings in English, due to the complexity of writing in a foreign language. 
Another study, conducted by Bae and Lee (2012) explored the enhancement of English writing skills of 42 pupils who participated in an extensive EFL programme over the course of 18 months, receiving 315 additional lessons. The pupils were aged from 9 to 13 and their English writing skills were tested three times during the programme. The measured subskills were grammar, content, coherence, text length and spelling. During the course of the study, the pupils consistently progressed in grammar, coherence and text length, with text length improving the fastest. The progression of spelling and content was not linear, but both still showed improvement at the final testing. The study has significance in developing writing skills in a foreign language, proving that systematic and longitudinal focus on developing writing skills brings positive results.

In their research, Perez-Paredes and Sanchez-Tornel (2014) examined the use of adverbs by learners in grades 5, 6, 9 and 10. Their aim was to establish whether the use of adverbs increases with age. The data was taken from the Polish, Spanish and Chinese Corpus of Crosslinguistic Interlanguage (ICCI) with the focus on 'food' and 'money' topics. Their study showed a significant increase in the use of adverbs with the age, and concluded that pupils up to grade 9 are less likely to use adverbs.

In her master's thesis, Župan (2017) researched the main characteristics of 110 English texts written by Year 6 pupils at the Slovene national exam in the school year 2013/14. They were analysed according to text length, lexical density, the most common mistakes, the most common two- and three-word phrases and readability. The 50 most often used words and word groups were compared to the corpus New General Service List (New-GSL) and CEFR (Common European Framework of Reference) language levels. The results showed that an average text was 72.06 words long, the lexical density was $10.20 \%$ (Urés method ${ }^{1}$ ), and the most common mistakes were grammatical. The 10 most often used words were 'in', 'be', 'I', 'you', 'a', 'can', 'and', 'the, 'do' and 'town'. Overall, $78.8 \%$ of the first 50 most often used words were also listed in the first 500 words in the corpus New-GSL; 90.4 to $96.2 \%$ words were level A1 according to CEFR, the rest were level A2. The research also showed that among the top 50 most often used words the most common word groups are nouns $(28.8 \%)$, verbs $(19.2 \%)$, pronouns (13.5\%), and prepositions (13.5\%). The most seldom used word groups were adverbs (9.6\%), adjectives (5.8\%), conjunctions $(5.8 \%)$ and particles (3.8\%). The most often used two-word phrases were 'in the', 'live in' and 'it is', and three-word phrases 'I live in', 'a lot of' and 'in your town'. The Gunning Fog readability index was 3.8 on average, which is a slightly higher result than expected, as the pupils had been formally learning English for approximately three years. This study is the most relevant for the current research, since it was conducted in the same setting and used similar tools for text analysis.

\section{The Study}

The aim of this study was to analyse the written summaries of Year 5 pupils in terms of content, general concepts of coherence, length and most often used words.

\subsection{Research Questions}

1. How many pupils can write a summary in the limited time available following and considering the content structure (the introduction, main body and conclusion)?

2. What is the average length of pupils' summaries?

Ure's method to measure lexical density: lexical density = (the number of lexical items x 100): the total words (Ure 1971). 
3. Which words and word classes do pupils use most often?

4. To what extent do most frequently used words in summaries correspond to the New General Service List?

5. At which $\mathrm{CEFR}^{2}$ level are the first 50 most often used words in the summaries?

6. What is the readability level of the summaries according to the Gunning Fog Index?

\subsection{Method and Participants}

\subsubsection{Method}

The research questions are quantitatively oriented, as they require data collection, analysis and interpretation to prove the main aim of this study. Several tools for analysing texts were used: Text Inspector, LancsLex and Textalyser. Text Inspector is the professional web tool for analysing texts. LancsLex is a tool that "analyses lexical coverage of texts and compares it to the New General Service List that identifies 2,490 most frequent words in the English language" (Brezina 2014). The tool examines lexical diversity and text complexity. Textalyser is an online text analysis tool which offers detailed statistics of the text, such as text length, lexical density and frequencies of words.

While there are numerous lists of frequent lexical items in English, the most used is West's General Service List (GSL). To improve the existing GSL List, a New General Service List was developed. It is based on four language corpora (LOB, BNC, BE06 and EnTenTen12) and consists of 13 billion running words (Brezina and Gablasova 2015).

The Gunning Fog Index is a readability test for texts written in English. It estimates the years of formal education a person needs to understand the text on the first reading (Tuckyta, Risagarniwa, and Sopian 2017). The formula for Gunning Fog is (Gunning 1952):

$$
\begin{array}{ll}
\text { Reading Level }(\text { Grade })=\quad \begin{array}{l}
\text { (Average number of words in sentences } \\
\text { words of three or more syllables }) \times 0.4
\end{array} & \text { Percentage of }
\end{array}
$$

where complex words are defined as those containing three or more syllables. For example, technical documents usually reach a Fog Index between 10 and 15, while professional prose seldom exceeds 18 (Tuckyta, Risagarniwa, and Sopian 2017).

\subsubsection{Participants}

A total of 64 Year 5 pupils participated in this study. The pupils were 10 or 11 years old. By the time of the study, the pupils had completed 280 lessons of English language learning from Year 1 to Year 4. Prior to commencing the study, consent was sought from their parents or legal guardians.

\subsection{Study Background}

The process of developing summary writing skills already started at the beginning stages of learning English as a foreign language, by exposing pupils to stories, which offered a rich source

The Common European Framework (CEFR) of six broad levels gives an adequate coverage of the learning space relevant to European language learners: Breakthrough (A1), Waystage (A2), Threshold (B1), Vantage (B2), Effective Operational Proficiency (C1), Mastery (C2). "A" covering the basic user, "B" the independent user and "C" the proficient user. 
of language. In the later stages when pupils were able to detect the key words of the story, the teacher helped them to organize the words into meaningful sentences and then into an organized text. This process took four years, and throughout all this time it was closely supported by the teacher. In the first years, all summaries were written by the teacher with the help of the students. In Year 4 pupils gradually started writing their own summaries, first in pairs and then individually. Before writing the summaries, they practiced the phrases and structures appearing in the story orally through various activities, such as role-play and only later on started with the writing tasks. These needed to be more guided at first, e.g. putting the story in the correct order, gap fill and matching activities. Answering the questions in full sentences in the written form and describing the pictures were final activities before writing the whole summary.

\subsection{Study Context}

The aim of developing writing skills in the present study was that Year 5 pupils would be able to write a summary of a story individually and in a given time frame. The task was approached gradually and systematically throughout the school year. The pupils were faced with a challenge of writing summaries of three different stories. To enhance writing skills by writing summaries was a decision based on the still relatively limited vocabulary and very basic grammar knowledge of the pupils at this level/age, and by reading the story first the pupils were provided with the context, necessary vocabulary and grammar structures as support. The teacher's approach in this study was story-based; the pupils did not use course books.

The first summary writing was based on the book 101 Dalmatians re-told for young learners by Marie Crook (Penguin Kids, Level 3, 600 headwords, CYLET: Starters). As motivation and to enhance comprehension, pupils first watched the animated film 101 Dalmatians produced by Walt Disney in 1961 and based on the novel The Hundred and One Dalmatians by Dodie Smith. Afterwards, they read the book and did a number of activities on the worksheets prepared by their teacher to expand vocabulary and improve story comprehension, for example, marking the statements as true or false, putting the story in the correct order, matching parts of the sentences, gap fill exercises and answering the questions related to the story. Two significant processes for writing a summary had already been introduced in Year Four, namely the use of keywords and the writing of a mind map. The process of writing a draft was introduced with this story.

Prior to composing the draft the pupils listed the keywords of the story, which the teacher wrote on the board to be available to everybody. The first summary writing task was done in pairs in order to create a safe and nurturing learning environment for the pupils with ample time to complete the task. One lesson (45 minutes) was dedicated solely to the composition of the draft, in which the division of the summary into introduction, main part (body) and conclusion should have been transparent. In addition, the pupils could use all the learning materials which were available to look up words or even copy some sentences while writing the draft, which relieved them of achievement pressure. The aim was to focus on the process of writing, where there is no need for fear of writing, where mistakes are an opportunity to enhance writing abilities and not something to be judged by. The decision to use the available support had to be made before they started working on the draft, and they had to make a simple note of no help or with help on their writing papers.

The next step was writing the summary of the story using their draft. The writing time was limited to 2 lessons. Afterwards, the teacher rewrote the pupils' summaries (in a typed manner) without their errors. The pupils compared their writing with the corrected teacher's version and 
tried to find their mistakes. As the next step, the pupils completed a self-assessment sheet, which was later talked through individually with the teacher who also supplied additional feedback on their writing. The pupils copied the corrected version of their summaries in their notebooks. The self-assessment sheet enabled the pupils to reflect on their writing; regarding the structure (introduction, main body, and conclusion), the content (the key events of the story), vocabulary, and intelligibility at a sentence level. In order to make the content criteria comprehensible for the pupils at this age to check, the key events of the story were written as content guidelines on the self-assessment sheet, and the pupils ticked them off as they were assessing their summaries.

The second story was Nail Soup. As an introduction and motivational tool, the pupils played a blind-folded guessing game, trying to recognize some of the key items from the story by touching them (an onion, a potato, a carrot, a pot). Listening to an authentic recording of the story (Bedtime Stories 2004) followed. The teacher checked the pupils' comprehension of the story by encouraging them to tell a brief summary. Basic story vocabulary was reinforced with a worksheet. The second listening to the story was accompanied by simultaneous reading of the printed version of the story. As a result, the pupils all confirmed their comprehension of the story to be much better on their second attempt. A number of activities and worksheets prepared by their teacher followed. The first activity was rapid word recognition, which was redone during the last lesson of the topic with a much higher rate of success than the first time. Among the activities were also classifying the words into semantic groups, putting the story into the correct order (two different versions) and other exercises similar to the ones in the previous story, yet linguistically more challenging than in the course of the first story. The next step towards pupils becoming "autonomous writers" was the individual writing of the second summary in a shorter time, i.e. in one lesson. The time frame intended for the draft stayed the same (one lesson). To further support the safe and nurturing learning environment, pupils could still use all learning materials when writing the draft, but this time only to look up words. Surprisingly, when the choice of using learning materials as a writing aid was offered to the pupils, many of them saw it as a challenge to try to write without the use of such materials, and were very keen to try to rely on their memories. The same steps as in the case of the first summary followed: teacher's correction of the summaries, pupils' comparison of the original and the corrected summary, pupils' self-assessment, teacher's individual feedback on their writing, and pupils' rewriting the corrected version.

The third story was San Francisco Story by John Escott (Penguin Readers, Easystarts, 200 headwords). As an introduction, the pupils listened to and sang two songs from different decades about San Francisco, the classic San Francisco by Scott McKenzie (1967) and a more recent one: Save me San Francisco by Train (2009). In continuation, the pupils watched two short documentaries about the earthquake in San Francisco: 1906 San Francisco Earthquake (https://www.youtube.com/watch?v=gebK-F4D1k) and the 1906 - San Francisco Earthquake - Eyewitness Account by Jack London (https:// www.youtube.com/watch?v=1 uhDTdQ6AWA) to get familiar with the theme. First, the pupils silently read the story on their own. In pairs, they read the story again to each other, allowing time for improving pronunciation and checking vocabulary comprehension. This was again followed by a number of writing tasks and worksheets prepared by their teacher. The tasks were similar to the ones in the previous two stories, but this time the teacher offered less support, so the pupils were expected to work autonomously. Before writing the summary, the revision of the vocabulary and phrases from the story was carried out in three stages using the mini white boards: translating words and phrases from Slovene to English, translating sentences from Slovene to English and answering the questions in full sentences. As previously, summary writing was an individual task, but the pupils could not use any materials to help them with their writing, and the writing time 
for the draft and the summary was limited to one lesson only. The same steps as in the case of the first and second summaries followed: teacher's correction of the summaries, pupils' comparison of the original and the corrected summaries, pupils' self-assessment, teacher's individual feedback on their writing, and pupils' rewriting the corrected versions. The third summary was seen as the final step towards becoming an independent summary writer in a foreign language in Year 5. As one of the main aims was to prove to the pupils that they could become confident and effective users of written language, the grammatical and spelling aspects of their writings were intentionally not included in the analysis. The grammar and spelling mistakes were corrected but no specific attention was drawn to them. Every individual summary was discussed with the author with regard to text organization, content and mistakes.

As explained above and briefly summarized in Table 1 below, the level of difficulty increased gradually and systematically regarding different types of grouping, use of learning materials while writing, and the time frame.

TABLE 1. A systematic increase of the level of difficulty in summary writing

\begin{tabular}{|c|c|c|c|c|}
\hline \multirow[t]{2}{*}{ STORY } & \multirow{2}{*}{$\begin{array}{l}\text { PAIR or } \\
\text { INDIVIDUAL } \\
\text { WRITING }\end{array}$} & \multirow{2}{*}{$\begin{array}{l}\text { USE OF LEARNING } \\
\text { MATERIALS } \\
\text { while writing the } \\
\text { draft }\end{array}$} & \multicolumn{2}{|c|}{ TIME FRAME } \\
\hline & & & DRAFT & SUMMARY \\
\hline $\begin{array}{l}101 \\
\text { Dalmatians }\end{array}$ & pair writing & allowed & 1 lesson & 2 lessons \\
\hline $\begin{array}{l}\text { Nail } \\
\text { Soup }\end{array}$ & $\begin{array}{l}\text { individual } \\
\text { writing }\end{array}$ & $\begin{array}{l}\text { allowed, but only to } \\
\text { look up words }\end{array}$ & 1 lesson & 1 lesson \\
\hline $\begin{array}{l}\text { San Francisco } \\
\text { Story }\end{array}$ & $\begin{array}{l}\text { individual } \\
\text { writing }\end{array}$ & not allowed & \multicolumn{2}{|l|}{1 lesson } \\
\hline
\end{tabular}

The present study is based on the last summary, i.e. San Francisco Story, which was written individually in one lesson, without any additional help.

\section{Results}

The results are presented in six sections according to the main research areas.

\subsection{Completion of Summary, Content and Structure}

As seen in Table 2, most of the pupils (73.4\%) managed to finish a structurally organized summary. Only $6.3 \%$ of those who had written a finished summary did not consider the general concepts of coherence, and did not divide their writing into an introduction, main body and conclusion paragraph. Regarding the content only, $79.7 \%$ of the pupils wrote a summary which included the most important aspects of the story. $15.6 \%$ of pupils were still not able to finish the summary in the time given. All but one pupil (who did not understand the whole story) noted not having enough time as the reason for not finishing the summary. Only $3.1 \%$ of pupils did not try writing in English but chose Slovene instead, and just one pupil (1.6\% of the total) wrote an incomprehensible summary in English, one that had too many language and content-related 
inadequacies to be understood. The incomprehensibly written summary and the two summaries written in Slovene were excluded from further analysis.

TABLE 2. Summary writing, $\mathrm{N}=64$.

\begin{tabular}{|l|l|l|l|l|}
\hline Incomprehensibly & $\begin{array}{l}\text { Summary } \\
\text { written in } \\
\text { Slovene }\end{array}$ & $\begin{array}{l}\text { Unfinished } \\
\text { summary }\end{array}$ & $\begin{array}{l}\text { Finished, } \\
\text { structurally } \\
\text { not organized } \\
\text { summary }\end{array}$ & $\begin{array}{l}\text { Finished, } \\
\text { structurally } \\
\text { organized } \\
\text { summary }\end{array}$ \\
\hline $1(1.6 \%)$ & $2(3.1 \%)$ & $10(15.6 \%)$ & $4(6.3 \%)$ & $47(73.4 \%)$ \\
\hline
\end{tabular}

We were pleasantly surprised that $50.8 \%$ of all pupils who wrote a comprehensible text in English included all 13 content guidelines in their summaries. The guidelines were in the form of 13 consecutive statements about the key events and facts in the story, which should have been included in the summary in order to meet the criteria for a coherent text. The content guidelines of San Francisco Story were: 1. Mr. Tyson owns a shop in San Francisco. 2. Ben needs a job. 3. Mr. Tyson offers Ben a job and a place to stay. 4. Mr. Tyson has a daughter called Lucy. 5. Jed is jealous because Lucy likes Ben. 6. Jed steals some money and leaves it in Ben's room. 7. Mr. Tyson fires Ben thinking he is a thief. 8. Ben sleeps in a park. 9. There is an earthquake. 10. Jed steals some money again. 11. Jed does not help Lucy during the earthquake, but Ben does. 12. Lucy and Mr. Tyson find out Jed is the thief. 13. Mr. Tyson, Lucy and Ben stay together in San Francisco. In the vast majority of summaries $(80.3 \%)$ ten or more guidelines were considered. Less than a half of the guidelines were included in the text in only $8.2 \%$ of the summaries.

TABle 3. Content adequacy of the summaries, $\mathrm{N}=61$.

\begin{tabular}{|c|c|}
\hline $\begin{array}{c}\text { Number of guidelines } \\
\text { included in the summary }\end{array}$ & Number of summaries \\
\hline 13 (all) & $31(50.8 \%)$ \\
\hline 12 & $9(14.8 \%)$ \\
\hline 11 & $4(5.6 \%)$ \\
\hline 10 & $5(8.2 \%)$ \\
\hline 9 & $2(3.3 \%)$ \\
\hline 8 & $1(1.6 \%)$ \\
\hline 7 & $3(4.9 \%)$ \\
\hline 6 & $2(3.3 \%)$ \\
\hline 5 & $3(4.9 \%)$ \\
\hline 4 & $1(1.6 \%)$ \\
\hline
\end{tabular}

TABLE 4. The three most often included guidelines, $\mathrm{N}=61$.

\begin{tabular}{|c|c|c|}
\hline $\begin{array}{c}\text { Position of the guideline } \\
\text { in the story sequence }\end{array}$ & The most often included guidelines & $\begin{array}{c}\text { Number of } \\
\text { inclusions }\end{array}$ \\
\hline 1 & Mr. Tyson owns a shop in San Francisco. & $61(100 \%)$ \\
\hline 2 & Ben needs a job. & $60(98.4 \%)$ \\
\hline 6 & $\begin{array}{c}\text { Jed steals some money and } \\
\text { leaves it in Ben's room. }\end{array}$ & $58(95.1 \%)$ \\
\hline
\end{tabular}


TABLE 5. The three least often included guidelines, $\mathrm{N}=61$.

\begin{tabular}{|c|c|c|}
\hline $\begin{array}{c}\text { Position of the guideline } \\
\text { in the story sequence }\end{array}$ & $\begin{array}{c}\text { The least often included } \\
\text { guidelines }\end{array}$ & Number of inclusions \\
\hline 10 & Jed steals some money again. & $43(70.5 \%)$ \\
\hline 12 & $\begin{array}{c}\text { Lucy and Mr. Tyson find out Jed is } \\
\text { the thief. }\end{array}$ & $45(73.8)$ \\
\hline 13 & $\begin{array}{c}\text { Mr. Tyson, Lucy and Ben stay } \\
\text { together in San Francisco. }\end{array}$ & $47(77 \%)$ \\
\hline
\end{tabular}

\subsubsection{Omission of Direct Speech}

Since the book San Francisco Story is categorized as part of the 'Easystarts' series, the use of direct speech in the book is very common. One of the key summary writing skills is learning to omit direct speech, and most of the summaries $(83.6 \%)$ were indeed written without any of this.

\subsection{The Length of the Summaries}

The average summary was composed of 15.1 sentences and the average sentence consisted of 7.7 words, which resulted in 119.8 words being written in the average summary and 57.3 of these were unique tokens (words) as individual occurrences of a linguistic unit in speech or writing.

TABLE 6. Sentence count, sentence length, word count and unique tokens, $N=61$

\begin{tabular}{|l|c|}
\hline & Average summary \\
\hline Sentence count & 15.1 \\
\hline Sentence length in words & 7.7 \\
\hline Word count & 119.8 \\
\hline Unique tokens & 57.3 \\
\hline
\end{tabular}

\subsection{Most Often Used Word Classes}

As expected, nouns $(3,179$ in total) were the most often used word class in the summaries, followed by verbs (1,373 in total) and determiners/articles (627 in total). Modals (only 27 in total) and possessive pronouns (29 in total) were the least often used.

TABLE 7. Most often used word classes in summaries, $\mathrm{N}=61$.

\begin{tabular}{|l|c|}
\hline Word class & Number in total \\
\hline Noun & 3179 \\
\hline Verb & 1373 \\
\hline Determiner, article & 627 \\
\hline Preposition/subord. conj. & 500 \\
\hline Personal pronoun & 323 \\
\hline Adjective & 311 \\
\hline Coordination conjunction & 224 \\
\hline Adverb & 209 \\
\hline
\end{tabular}




\begin{tabular}{|l|c|}
\hline Cardinal number & 66 \\
\hline Determiner & 57 \\
\hline Possessive pronoun & 29 \\
\hline Modal & 27 \\
\hline
\end{tabular}

\subsection{Most Frequently Used Words in Summaries in Correspond- ence with the New General Service List}

As Table 8 shows, the five most frequently used words in the summaries coincide with the first seven words ranked by the New-GSL (rank 3, 6, 2, 1 and 7). However, regarding the content of the book, it was to be expected that some frequently used words in the summaries would not be found in the first 500 words of the New-GSL but much later on the list of the first 2500 core vocabulary words, like "store" (rank 1938) and "safe" (rank 1109), both used as nouns. The words "earthquake" and "jealous" which take $23^{\text {rd }}$ and $35^{\text {th }}$ place on the list of most frequently used words in the analysed summaries, are not listed in the New-GSL.

\subsection{CEFR Level of the First 50 Most Often Used Words in the Summaries}

Of the 50 most often used words in the summaries, 45 (90\%) are level A1, one is level A2 (offer - verb), three are B1 (store - noun, thief, jealous) and one B2 (earthquake). This result was partly expected, since the book is categorized as level A1 according to the CEFR criteria.

TABLE 8. Most frequently used words in summaries in correspondence with the New General Service List and CEFR level of the 50 most often used words in the summaries.

\begin{tabular}{|l|l|c|c|c|}
\hline $\begin{array}{l}\text { Occurrence rank } \\
\text { in summaries }\end{array}$ & Word & $\begin{array}{c}\text { Occurrence frequency } \\
\text { in summaries }\end{array}$ & $\begin{array}{c}\text { Rank by } \\
\text { New-GSL }\end{array}$ & CEFR \\
\hline 1 & and & 323 & 3 & $\mathrm{~A} 1$ \\
\hline 2 & $\mathrm{a}$ & 315 & 6 & $\mathrm{~A} 1$ \\
\hline 3 & be & 311 & 2 & $\mathrm{~A} 1$ \\
\hline 4 & the & 282 & 1 & $\mathrm{~A} 1$ \\
\hline 5 & in & 214 & 7 & $\mathrm{~A} 1$ \\
\hline 6 & he & 207 & 11 & $\mathrm{~A} 1$ \\
\hline 7 & money & 171 & 264 & $\mathrm{~A} 1$ \\
\hline 8 & store (noun) & 139 & 1938 & $\mathrm{~B} 1$ \\
\hline 9 & job & 118 & 307 & $\mathrm{~A} 1$ \\
\hline 10 & to & 109 & 7 & $\mathrm{~A} 1$ \\
\hline 11 & have & 93 & 8 & $\mathrm{~A} 1$ \\
\hline 12 & help & 79 & 185 & $\mathrm{~A} 1$ \\
\hline 13 & take & 79 & 46 & $\mathrm{~A} 1$ \\
\hline 14 & safe (noun) & 71 & 1109 & $\mathrm{~A} 1$ \\
\hline 15 & need & 68 & 117 & $\mathrm{~A} 1$ \\
\hline 16 & not & 67 & 21 & $\mathrm{~A} 1$ \\
\hline 17 & thief & 67 & 166 & $\mathrm{~B} 1$ \\
\hline
\end{tabular}




\begin{tabular}{|c|c|c|c|c|}
\hline 18 & bag & 64 & 1337 & $\mathrm{~A} 1$ \\
\hline 19 & small & 60 & 166 & $\mathrm{~A} 1$ \\
\hline 20 & day & 55 & 95 & A1 \\
\hline 21 & one & 55 & 36 & $\mathrm{~A} 1$ \\
\hline 22 & daughter & 51 & 934 & $\mathrm{~A} 1$ \\
\hline 23 & earthquake & 51 & off list & $\mathrm{B} 2$ \\
\hline 24 & work & 49 & 122 & $\overline{\mathrm{A} 1}$ \\
\hline 25 & from & 48 & 24 & $\mathrm{~A} 1$ \\
\hline 26 & room & 47 & 289 & $\mathrm{~A} 1$ \\
\hline 27 & say & 45 & 32 & $\mathrm{~A} 1$ \\
\hline 28 & do & 44 & 22 & $\mathrm{~A} 1$ \\
\hline 29 & it & 42 & 12 & $\mathrm{~A} 1$ \\
\hline 30 & sleep & 42 & 1507 & $\overline{\mathrm{A} 1}$ \\
\hline 31 & go & 41 & 47 & $\overline{\mathrm{A} 1}$ \\
\hline 32 & like & 41 & 242 & $\overline{\mathrm{A} 1}$ \\
\hline 33 & run & 41 & 200 & $\overline{\mathrm{A} 1}$ \\
\hline 34 & park & 41 & 1483 & $\mathrm{~A} 1$ \\
\hline 35 & jealous & 41 & off list & B1 \\
\hline 36 & because & 37 & 96 & $\mathrm{~A} 1$ \\
\hline 37 & into & 37 & 53 & $\mathrm{~A} 1$ \\
\hline 38 & there & 35 & 129 & $\mathrm{~A} 1$ \\
\hline 39 & put & 34 & 150 & $\mathrm{~A} 1$ \\
\hline 40 & but & 33 & 23 & $\mathrm{~A} 1$ \\
\hline 41 & that & 32 & 9 & $\mathrm{~A} 1$ \\
\hline 42 & some & 31 & 48 & $\mathrm{~A} 1$ \\
\hline 43 & stay & 31 & 442 & $\mathrm{~A} 1$ \\
\hline 44 & offer & 29 & 285 & $\mathrm{~A} 2$ \\
\hline 45 & give & 27 & 74 & $\mathrm{~A} 1$ \\
\hline 46 & now & 27 & 72 & $\mathrm{~A} 1$ \\
\hline 47 & together & 27 & 238 & $\mathrm{~A} 1$ \\
\hline 48 & think & 25 & 91 & $\mathrm{~A} 1$ \\
\hline 49 & know & 24 & 61 & $\mathrm{~A} 1$ \\
\hline 50 & $\operatorname{man}$ & 23 & 105 & $\overline{\mathrm{A} 1}$ \\
\hline
\end{tabular}

\subsection{The Readability Level of the Summaries according to the Gunning Fog Index}

The average Gunning Fog Index is 4.11.

\section{Discussion}

The present study demonstrates that young learners (Year 5, age 10 or 11) can write a summary of a story individually and in a given time frame. The emphasis was on a systematic and gradual approach of developing writing skills, which was achieved by multiple summary writings during one school year. 
Encouragingly, most of the pupils $(73.4 \%)$ managed to finish a structurally organized summary and only $15.6 \%$ of the pupils were not able to finish it in the given time frame. Only $6.3 \%$ of all the pupils wrote a complete summary without considering the general concepts of coherence (the introduction, main body and conclusion). Just $3.1 \%$ of the pupils did not feel confident enough to write in English, so they chose Slovene instead, and only 1.6\% of the pupils wrote an incomprehensible summary in English. One of the more significant findings to emerge from these results is that pupils can master key (summary) writing skills when the teacher provides them with direct instruction and practice over a longer period of time.

Regarding the content, over a half of the pupils (50.8\%) who wrote a comprehensible text in English included all 13 content guidelines in their summaries. Ten or more guidelines were considered in more than $80 \%$ of the summaries. The three most often included guidelines, with a percentage of inclusion ranging from 100 to $95.1 \%$, were from the first half of the story, the first guideline being the one with a $100 \%$ percentage inclusion. The three least often included guidelines, with a percentage of inclusion ranging from 70.5 to $77 \%$, were from the last third of the story. Discussing the key events of the story and the order in which they happened before writing a summary helped pupils to include most of them in their writing. However, as the results indicate, the first events in the story were more memorable for the pupils than the events that happened towards the end. With regard to the omission of direct speech, the vast majority of the summaries $(83.6 \%)$ were indeed written without any use of it, again due to the fact that the form of reporting events in the story was addressed during the lessons.

Further analysis showed that the average summary was composed of 15.1 sentences and the average sentence consisted of 7.72 words, which resulted in 119.8 words being written in the average summary and 57.3 of these were unique tokens. In comparison to the results of the study conducted by Župan (2017), where the average length of the written composition of Year 6 pupils at the National Exam in English was 72.1 words, Year 5 pupils in the present study wrote texts which were 47.73 words longer. Lindgren and Stevenson (2013) examined Swedish pupils' (aged 11 or 12) writing and determined that they wrote texts with 281.5 characters on average, whereas Slovene Year 5 pupils in the present study included 459.3 characters in an average text, and thus used 177.8 (38.7\%) more characters in their summaries compared to the Swedish pupils. Bae and Lee (2012) measured the text length three times during their study. In comparison to Slovene Year 5 pupils with 119.8 words per average summary, South Korean pupils (aged 9 to 13) wrote longer texts at each measurement: 125.9 words at the first measurement, 191.9 words at the second measurement, and 267 words at the third measurement; which shows that South Korean pupils already outdid Slovene pupils in their initial attempts. The reason for this improvement from the first to the third measurement could be found in the intensive learning process used in the South Korean study: a total of 315 hours of instruction just over the 18-month period. In comparison with the Slovene pupils, most of the South Korean pupils in the study were 2-3 years older and had a much larger exposure to the English language than their Slovene counterparts. In another study, in which the participants were 5, 6, 8, and 9-graders (aged between 11 and 16) from different countries, Perez-Paredes and Sanchez-Tornel (2014) established that Chinese learners wrote the largest number of words per essay (99.9), followed by Polish (87.2) and Spanish students (75.1). Comparing the two studies, Slovene Year 5 pupils wrote longer texts than any of the nations included in Perez-Paredes and Sanchez-Tornel's (2014) research. The Slovene summaries were 16.6\% longer than the Chinese texts, $27.2 \%$ longer than the Polish texts, and even $37.3 \%$ longer than the Spanish texts. The results can be explained by the systematic approach to developing writing skills which was utilized in the present study. 
The results of the current study showed the expected frequency regarding the use of word classes: nouns $(3,179$ in total) were the most frequently used word class in the summaries, followed by verbs (1,373) and determiners/articles (627). Modals (only 27) and possessive pronouns (29) were the least often used word classes from the list. Comparing the word classes by frequency between the writing compositions of Year 6 pupils at the National Exam in English (Župan 2017) and the summaries written by Year 5 pupils, it can be established that the same word classes take the first two places, i.e. nouns and verbs. The frequencies of the other word classes in the writing compositions of Year 6 pupils at the National Exam in English (Župan 2017) were in the following order: pronouns, prepositions, adverbs, adjectives, conjunctions, and articles. In contrast in the summaries the order was: determiners/articles, prepositions/subordination, conjunctions, pronouns, adjectives, coordination conjunctions, and adverbs. It is interesting to note that articles are very high on the list for Year 5 pupils but in the last place for Year 6 pupils. This could be due to the emphasis placed on the use of articles by the teachers during lessons. In our case, the teacher consistently used the articles in the English class herself and encouraged the pupils to use them as well, first in the form of simple repetition and then step-by-step explanation of the correct use of the articles in an age appropriate manner. Stories are a great source of texts which introduce the use of the articles in a meaningful context. Moreover, there is little emphasis on explicit teaching of the pronouns in English classes up to Year 6, which could explain the discrepancy in the use of pronouns between the pupils in Župan's study (2017) and the present work.

The five most frequently used words in the summaries ("and", "a”, "be", "the", "in") coincide with the first seven words ranked by the New-GSL ( $\operatorname{rank} 3,6,2,1$ and 7). Comparing the results with Župan's (2017) research, in which the first five most frequently used words were "in”, "be", "I", "you", and "a", three of the five words correspond to the five most frequently used words in the summaries in the present study. Both studies confirm the high frequency of the above mentioned words and are in accordance with the New-GSL ranking. Some frequently used words in the summaries were not found in the first 500 words of the New-GSL but much later, on the list of the first 2500 core vocabulary words, like "store" (rank 8 in the summaries, rank 1938 in the New-GSL) and "safe" (rank 14 in the summaries, rank 1109 in the New-GSL) both used as nouns. The words "earthquake" and "jealous", which took $23^{\text {rd }}$ and $35^{\text {th }}$ places on the list of the most frequently used words in the summaries, are not listed in the New-GSL. These words are not very frequent in the every-day context, but they appear in the book San Francisco Story as keywords, due to the content of the story. Consequently, the pupils were exposed to them very often in the classroom, and thus able to use them in their summaries.

As it was expected, since the book San Francisco Story is categorized as level A1, from the 50 most often used words in the summaries 45 (90\%) are level A1, one is level A2 ("offer" - verb), three are B1 ("store" - noun, "thief", "jealous") and one B2 ("earthquake") whereas in the written compositions of Year 6 pupils at the National Exam in English (Župan, 2017) all but the last three of the 50 most often used words ("can", "swimming", "church" - all level A2) were level A1. The B1 and B2 words used by the pupils in the present study were often repeated in the book San Francisco Story, the content of which was extensively discussed prior to writing the summaries. This study shows that pupils expand their vocabulary in a natural manner through experiencing the story in a multisensory way and through doing a variety of tasks related to the content of the story. Therefore, their vocabulary level is higher than the level of the pupils who are not exposed to the stories in such an extensive way. If the words are presented in an interesting context and there is enough meaningful repetition, the pupils do not perceive these words as difficult. 
The Gunning Fog Index of the analysed Year 5 pupils' summaries is 4.11, whereas that of the Year 6 pupils' texts at the National Exam in English was 3.8\% (Župan, 2017), showing that a systematic approach to writing can result in a better readability index of pupils' written products.

\section{Conclusion}

The issue of teaching and acquiring writing skills in a foreign language is broad and diverse. As primarily a reading and writing activity, summary writing tasks are an effective strategy for teaching writing skills. However, despite this, most foreign language teachers rarely include the development of this skill into their instruction. Consequently, foreign language pupils cannot develop it sufficiently, despite having a large number of FL lessons at schools. Teachers in EFL classrooms should not assume that their pupils will gradually master summary writing skills in the process of learning. They need to offer their students systematic practice and direct instruction over a long period of time. Therefore, a variety of activities should be included to help students develop their (summary) writing skills. The process itself starts well before the actual writing, with activities that help pupils understand the text and remember its content. When developing summary writing skills the teacher's focus should lie on the process of writing by helping pupils to learn the most important steps of summarizing, with finding the key ideas and excluding the unimportant information being two of these. Further significant aspects teachers should bear in mind are to give pupils enough time for writing and offer them supportive feedback on their work. The results of the present study might therefore encourage foreign language teachers not to use course books alone in their classes, but also to make some extra time for extensive and indepth reading of texts (stories in the case of early teaching of English) which enable the intensive development of writing skills in the form of summarization. Further research on developing EFL writing skills with primary school pupils is evidently an important issue which could include an analysis of other forms of writing (e.g. stories, compositions) and other models of developing processes in writing.

\section{References}

Bae, Jungok, and Yae-Sheik Lee. 2012. "Evaluating the Development of Children's Writing Ability in an EFL Context.” Language Assessment Quarterly 9 (4): 348-74. https://doi.org/10.1080/15434303.2012.721424.

Behrens, Laurence M., and Leonard J. Rosen, 2012. Writing and Reading across the Curriculum. Twelfth Edition. New York: Longman.

Brezina, Vaclav. 2014. “Analyse Your Texts with the New GLS.” Lancaster: Lancaster University Press. http://corpora.lancs.ac.uk/vocab/analyse.php.

Brezina, Vaclav, and Dana Gablasova. 2015. "Is There a Core General Vocabulary? Introducing the New General Service List.” Applied Linguistics 36 (1): 1-22. https://doi.org/10.1093/applin/amt018.

Brown, H. Douglas. 2001. Teaching by Principles: An Interactive Approach to Language Pedagogy. New York: Longman.

Brown, Ann L., and Jeanne D. Day. 1983. "Macrorules for Summarizing Texts: The Development of Expertise." Journal of Verbal Learning and Verbal Behavior 22 (1): 1-14. https://doi.org/10.1016/S00225371(83)80002-4.

Cho, Youngmyoung. 2012. "Teaching Summary Writing through Direct Instruction to Improve Text Comprehension for Students in ESL/EFL Classroom.” Master's Thesis, University of Wisconsin. 
Cushing Weigle, Sara. 2014. “Considerations for Teaching Second Language Writing.” In Teaching English as a Second or Foreign Language, Fourth Edition, edited by Marianne Celce-Murcia, Donna M. Brinton, and Marguerite Ann Snow, 222-37. Boston: Heinle Cengage.

Dagarin Fojkar, Mateja. 2014. "Literacy Development in Course Books for Teaching English in the Second Cycle of Slovenian Primary School.” Linguistica 54 (1): 153-66. https://doi.org/10.4312/ linguistica.54.1.153-166.

Dagarin Fojkar, Mateja, Urška Sešek, and Janez Skela. 2011. Sounds and Letters. Priročnik k delovnem zvezku za razvijanje opismenjevanja $v$ anglešcini kot tujem jeziku. Ljubljana: Tangram.

Friend, Rosalie. 2001. "Effects of Strategy Instruction on Summary Writing of College Students." Contemporary Educational Psychology 26: 3-24.

Gunning, Robert. 1952. The Technique of Clear Writing. New York: McGraw-Hill.

Hidi, Suzanne, and Valerie Anderson. 1986. "Producing Written Summaries: Task Demands, Cognitive Operations, and Implications for Instruction.” Review of Educational Research 56 (4): 473-93. https://doi. org/10.3102/00346543056004473.

Hill, Margaret. 1991. "Writing Summaries Promotes Thinking and Learning Across the Curriculum But Why Are They So Difficult to Write?” Journal of Reading 34 (7): 536-39. http://www.jstor.org/ stable/40014578.

Hirvela, Alan R. 2016. Connecting Reading \& Writing in Second Language Writing Instruction. Second Edition. Ann Arbor: The University of Michigan Press.

Johnson, Nancy. 1983. "What Do You Do If You Can't Tell the Whole Story? The Development of Summarization Skills.” In Children's Language Vol. 4, edited by Keith N. Nelson, 162-63. Hillsdale, NJ: Erlbaum.

Kirkland, Margaret R., and Mary Anne P. Saunders. 1991. "Maximizing Student Performance in Summary Writing: Managing Cognitive Load.” TESOL Quarterly 25 (1): 105-21. https://doi. org/10.2307/3587030.

Langan, John. 2015. Ten Steps to Advancing College Reading Skills. Sixth Edition. West Berlin, New Jersey: Townsend Press.

Lindgren Eva, and Marie Stevenson. 2013. "Interactional Resources in the Letters of Young Writers in Swedish and English.” Journal of Second Language Writing 22 (4): 390-405. https://doi.org/10.1016/j. jslw.2013.09.001.

Murphy, Victoria A. 2017. "Literacy Development in Children with English as an Additional Language (EAL)." In Early Language Learning. Complexity and Mixed Methods, edited by Janet Enever, and Eva Lindgren, 41-61. Bristol: Multilingual Matters.

Perez-Paredes, Pascual, and Maria Sanchez-Tornel. 2014. "Adverb Use and Language Proficiency in Young Learners' Writing.” International Journal of Corpus Linguistics 19 (2): 178-200. doi 10.1075/ ijcl.19.2.02per.

Program osnovna šola. Učni načrt: Angleščina. 2016. Ljubljana: Ministrstvo za šolstvo, znanost in šport, Zavod RS za šolstvo. http://www.mizs.gov.si/fileadmin/mizs.gov.si/pageuploads/podrocje/os/prenovljeni_ UN/UN_anglescina.pdf.

RIC. 2014. "Opisi dosežkov učencev 6. razreda in specifikacijske tabele preizkusov znanja NPZ 2014." http:// www.ric.si/preverjanje_znanja/statisticni_podatki/.

—. 2015. "Opisi dosežkov učencev 6. razreda in specifikacijske tabele preizkusov znanja NPZ 2015." http:// www.ric.si/preverjanje_znanja/statisticni_podatki/.

—. 2016. “Opisi dosežkov učencev 6. razreda in specifikacijske tabele preizkusov znanja NPZ 2016.” https:// www.ric.si/preverjanje_znanja/statisticni_podatki/. 
—. 2017. "Opisi dosežkov učencev 6. razreda in specifikacijske tabele preizkusov znanja NPZ 2017." http:// www.ric.si/preverjanje_znanja/statisticni_podatki/.

Rinehart, Steven D., and Karen F. Thomas. 1993. "Summarization Ability and Text Recall by Novice Studiers." Reading, Research and Instruction 32 (4): 24-32. https://doi.org/10.1080/19388079309558130.

Shih, May. 1986. “Content-Based Approaches to Teaching Academic Writing.” TESOL Quarterly 20 (4): $617-48$.

Stotsky, Sandra. 1995. "The Uses and Limitations of Personal or Personalized Writing in Writing Theory, Research, and Instruction." Reading Research Quarterly 30: 607-32.

Textalyser. 2004. http://textalyser.net/.

Text Inspector. 2015. Cambridge: Cambridge University Press. http://www.englishprofile.org/wordlists/textinspector.

Tuckyta, Eva Sari Sujanta, Yuyu Yohana Risagarniwa, and Rahmat Sopian. 2017. The Readability Test of the English Children Short Stories. International Conference on Language, Education, Humanities and Innovation. 21st \& 22nd January, 2017: 85-92. https://proceedings.icsai.org/5iclehi/5iclehi-076.pdf

Ure, Jean. 1971. "Lexical Density and Register Differentiation." In Applications of Linguistics: Selected Papers of the 2nd International Congress of Applied Linguists, edited by George Perren and John Leslie Melville Trimm, 443-52. London: Cambridge University Press.

Westby, Carol, Barbara Culatta, Barbara Lawrence, and Kendra Hall-Kenyon. 2010. "Summarizing Expository Texts.” Topics in Language Disorders 30 (4): 275-287. https://doi.org/10.1097/TLD.0b013e3181ff5a88.

Župan, Tina. 2017. “Značilnosti angleških pisnih besedil slovenskih šestošolcev.” Master’s Thesis, Faculty of Education, University of Ljubljana. 